\title{
The Afro-Asian cyclopoid Mesocyclops aspericornis (Crustacea: Copepoda) in eastern Mexico with comments on the distribution of exotic copepods
}

\section{El cyclopoide afro-asiático Mesocyclops aspericornis (Crustacea: Copepoda) en el este de México con comentarios sobre la distribución de copépodos exóticos}

\author{
Eduardo Suárez-Morales $^{1 *}$, Martha A. Gutiérrez-Aguirre ${ }^{2}$ and Fredy Mendoza ${ }^{3}$ \\ ${ }^{1}$ El Colegio de la Frontera Sur (ECOSUR), Unidad Chetumal. Apartado postal 424, 77014 Chetumal, Quintana Roo, Mexico. \\ ${ }^{2}$ Universidad de Quintana Roo. Campus Cozumel. Av. Andrés Quintana Roo, Calle 11 con Calle 110 Sur s/n, Col San Gervasio, 77642 Cozumel, \\ Quintana Roo, Mexico. \\ ${ }^{3}$ Departamento de Control de Enfermedades Transmitidas por Vector, Servicios de Salud del Estado de Veracruz. Soconusco Núm. 31 , Col. Aguacatal, \\ 91130 Jalapa, Veracruz, Mexico. \\ *Correspondent: esuarez@ecosur.mx
}

\begin{abstract}
The Afro-Asian freshwater copepod Mesocyclops aspericornis (Daday, 1906), deemed as an exotic species in the Americas, is known to occur disjunctly in Mexico, South America, and the insular Caribbean. Adult females of this species were recorded.from samples collected in the state of Veracruz, on the Atlantic coast of Mexico.The morphology of these specimens is identical in most characters to those described or depicted in previous taxonomic accounts. The 3 known Mexican populations belong to the "western" group of M. aspericornis. The subtle morphological variations among the Mexican populations and their isolation suggest that each could be the result of independent events of dispersion or introduction via aquaculture. This is the third confirmed report of $M$. aspericornis in Mexico, but the first one in the Atlantic side of Middle America. The states of Tabasco and Chiapas harbour 3 of the 4 species of exotic freshwater copepods known to occur in Mexico.
\end{abstract}

Key words: exotic crustaceans, copepods, freshwater zooplankton.

Resumen. El copépodo dulceacuícola afro-asiático Mesocyclops aspericornis (Daday, 1906), considerado como especie exótica en América, se sabía presente de modo disperso en México, Sudamérica y en las islas del Caribe. A partir de muestras recolectadas en el estado de Veracruz, en la costa del Atlántico de México, se registraron hembras adultas de esta especie. La morfología de estos ejemplares es idéntica en la mayoría de los caracteres a la descrita o ilustrada en trabajos taxonómicos previos. Las 3 poblaciones conocidas en México pertenecen al grupo "occidental" de $M$. aspericornis. Las sutiles variaciones morfológicas entre las poblaciones mexicanas y su aislamiento sugieren que cada una podría ser resultado de eventos independientes por dispersión o introducción vía la acuacultura. Este es el tercer registro confirmado de M. aspericornis en México, pero el primero en Mesoamérica en el lado del Atlántico. Los estados de Tabasco y Chiapas alojan 3 de las 4 especies de copépodos exóticos de aguas continentales que se conocen en México.

Palabras clave: crustáceos exóticos, copépodos, zooplancton de aguas continentales.

\section{Introduction}

The knowledge of the non-indigenous aquatic fauna in Mexico is still in development and the occurrence of these forms represents a danger to biodiversity worldwide. Unfortunately, there are no legislations regarding the control and monitoring of the many cases of non-indigenous aquatic species (NAS) already recorded in Mexico (Okolodkov et al., 2007). Hence, it is important to detect the occurrence of these species and track their advance on

Recibido: 24 marzo 2009; aceptado: 28 mayo 2010 the continent. According to the NAS Program (http://nas. er.usgs.gov) of the U.S. Geological Survey, several exotic species of freshwater cyclopoid copepods, including some Mesocyclops, have invaded North America. One of those not recorded yet in North America is M. aspericornis (Daday, 1906). It has a widespread distribution in tropical areas of Asia and Africa (Van de Velde, 1984; Holyńska et al., 2003) and has long been considered as an exotic form in the Americas (Reid and Saunders, 1986; Holyńska et al., 2003). This is probably the most widespread Afro-Asian Mesocyclops on the continent. In the Americas it has been recorded from the Caribbean islands and northern South America (see Suárez et al., 1984; Pesce, 1985; Reid and 
Saunders, 1986; Rocha and Botelho, 1998). It was not known from Mexico until the reports by Gutiérrez-Aguirre et al. (2003a) and ElíasGutierrez et al. (2008). Because of its size, mandibular structure, and predating features it has been promoted as an important potential option to become a biological control of mosquito larvae in the neotropics (Marten et al., 1994; Suárez-Morales et al., 2003).

The Mexican records of $M$. aspericornis include the state of Sinaloa, on the northwestern Pacific coast (Gutiérrez-Aguirre et al., 2003a), and the state of Morelos in central Mexico (Elías-Gutiérrez et al., 2008). During a series of biological surveys of the mosquito fauna of freshwater systems of the state of Veracruz, on the Atlantic coast of Mexico, a wide variety of freshwater habitats suitable for larval mosquitoes were sampled in different localities. Freshwater cyclopoid copepods have not been previously taxonomically surveyed in Veracruz (SuárezMorales and Reid, 1998). From the analysis of these collections, 2 adult female specimens of $M$. aspericornis were found at one of the localities. Herein w e report the unexpected occurrence of this exotic Afro-Asian species in this zone of Mexico. Our specimens were taxonomically examined in order to make a reliable identification of this species which belongs to a group of Afro-Asian forms that have subtle morphological differences (Holyńska, 2000). A comparison was made among specimens from the known populations from Mexico, Africa, and Asia. Comments are presented on the occurrence and current distribution of the other introduced freshwater cyclopoid copepods known in Mexico.

\section{Materials and methods}

The specimens examined were collected during routine surveillance for larval mosquitoes conducted by the Vector Department of the Health Ministry of the State of Veracruz, Mexico (Mendoza, 2007). Samples were obtained from different freshwater habitats in the central region of Veracruz at different times during 2007 and 2008. Samples of water were collected using hand-towed plankton nets, dippers $(330 \mathrm{ml})$, and pipettes in the potential mosquito habitats examined. Samples were fixed and preserved in formalin and then transferred to $70 \%$ ethanol. Copepods were sorted out and examined taxonomically. The dissected specimens were mounted in semi-permanent slides with glycerine sealed with Entellan ${ }^{\circledR}$. The specimens of $M$. aspericornis were deposited in the collection of zooplankton housed at El Colegio de la Frontera Sur (ECO-CHZ), in Chetumal, Mexico. The locality positive for M. aspericornis was a small pond located near El Castillo, Jalapa, Veracruz (19 ${ }^{\circ}$ $32^{\prime} 45^{\prime \prime} \mathrm{N}$; $96^{\circ} 51^{\prime}$ 44” W), sampled on September 18, 2007. The specimens were identified following Holyńska (2000) and Holyńska et al. (2003). Morphological observations were made under an E-200 Nikon standard compound microscope at 40 and $100 \mathrm{X}$ magnifications. Line illustrations of the taxonomically relevant appendages of M. aspericornis from Veracruz were prepared using a camera lucida.

\section{Description}

Order: Cyclopoida G.O. Sars, 1886

Family: Cyclopidae Rafinesque, 1815

Subfamily: Cyclopinae G.O. Sars, 1913

Mesocyclops aspericornis (Daday, 1906) (Figs. 1A-L)

The morphology of the female specimens from Veracruz agrees in general with the descriptions provided by Kiefer (1981), Van de Velde (1984), and Holyńska (2000). Total length, from anterior margin of cephalosome to distal margin of anal somite $=1.5-1.6 \mathrm{~mm}$. Cephalothorax width/ genital double-somite width ratio $=2.9$. Seminal receptacle with wide lateral arms, anterior margin deeply concave; the copulatory duct is strongly curved; transverse ducts are connected to copulatory pore, forming a "V".

The structure and ornamentation of the cephalic appendages and particularly of the antennules and antennae were examined in some detail. The antennules of the Veracruz specimens have spinules on segments 1, 4-5, 7-13 (Fig. 1A); this pattern is one of the main distinguishing characters of the species (Holyńska et al., 2003). The hyaline membrane on the last antennular segment is serrated, with a deep distal notch (Fig. 1B). It is identically built in the Mexican (Veracruz, Sinaloa and Morelos) (Gutiérrez-Aguirre et al., 2003a; Elías-Gutiérrez et al., 2008), the African, and the Asian (Van de Velde, 1984; Holyńska, 2000) specimens.

The antennal ornamentation of the Mexican specimens including those from Veracruz, Morelos, and Sinaloa has some interesting characters (Figs. 1C, D). These specimens have 2 secondary rows of spinules on the proximal ventral surface of the basipodite (arrow in Fig. 1D-2) vs. a single row in some African and Asian populations (see Van de Velde, 1984; Holyńska et al., 2003). The Mexican populations share this character with the South American forms (Holyńska et al., 2003). A distal row of 4-5 small spinules on the ventral surface of the antennal basipodite is present in the Sinaloa (Gutiérrez-Aguirre et al., 2003a, fig. 3B), the Morelos (Elías-Gutiérrez et al., 2008, fig. 52.3), and the Veracruz specimens (arrow in 




Figure 1. Mesocylops aspericornis (Daday, 1906), adult female from El Castillo, Jalapa, Veracruz, Mexico. A, antennule; B, antennule, detail of serrate hyaline membrane on segment 17; C, antennal basipod, anterior; D, antennal basipodite, posterior, showing distal (1) and proximal (2) secondary rows of spinules; E, antenna, second endopodal segment; F, maxilliped, syncoxa; G, leg 1, coxa, basipod, first endopodal segment, and intercoxal sclerite; H, leg 4, anterior view; I, inner margin of basipod of leg 4, anterior view; J, distal spines of third endopodal segment of leg 4 ; K, caudal rami, ventral view, and L, third exopodal segment of leg 4 . Scale bars $=50 \mu \mathrm{m}$. 
Fig. 1D-1); it is also present in west African and Brazilian specimens (Holyńska et al., 2003) but is absent in East African and Asian populations. The specimens of the 3 Mexican populations have 9 setae on the second segment of the antennal endopod (Fig. 1E; Elías-Gutiérrez et al., 2008); according to Holyńska et al. (2003) the Neotropical populations differ from the Asian ones (with 8 or 9 setae) by having less (7-8, sometimes 9$)$ setae.

The ornamentation of the mandibles, not described by Kiefer (1981) or van de Velde (1984) was first depicted by Holyńska (2000) and includes 3 groups of spinules near to the insertion of the palp; this character is clearly present in the Sinaloa, Morelos, and Veracruz specimens as well. The same is true for the maxillae, which has a single row of slender setae on the coxal surface in both groups of specimens. We observed the oblique row of minute spinules on the syncoxal surface of the maxilliped as reported by Holyńska (2000) (Fig. 1F). The ornamentation of the basipod of leg 1 is identical in the specimens from Mexico, including a distal row of spinules at the insertion of the endopod (Fig. 1G). The same is true for the ornamentation of the coxa of leg 4, except for the presence of an additional row of hair-like elements on medial surface in the Sinaloan specimens (Gutiérrez-Aguirre et al., 2003a: fig. 4C), which is not present in the Morelos females (Elías-Gutiérrez et al., 2008: fig. 52.7) or in the Veracruz specimens (Fig. 1H). The basipodite has the usual ornamentation of the species (Fig. 1I).

The Mexican populations show some additional differences and coincidences with respect to the African and Asian specimens (Kiefer, 1981, Van de Velde, 1984, Holyńska, 2000). The body size of the Sinaloa (1.14-1.20 $\mathrm{mm}, \mathrm{n}=10)$ and the Morelos (1.22-1.28 mm, $\mathrm{n}=3)$ adult females tends to be smaller than the Veracruz (1.5-1.6 $\mathrm{mm}, \mathrm{n}=2)$ and the African $(1.3-1.5 \mathrm{~mm})$ specimens. The ratio of length of the antennular segments $16 / 17$ is similar in specimens from Sinaloa, Morelos, and Veracruz (1.171.30); it is slightly lower in some African specimens (Van de Velde, 1984). The length/width ratio of the third endopodal segment of leg 4 in the Veracruz females (2.8) (Fig. 1H) is slightly greater than the range reported in the Sinaloa specimens (2.5-2.7) (Gutiérrez-Aguirre et al., 2003a). Despite the low number of comparative observations, it appears to be closer to the values of African populations recorded by Kiefer (1981).

The length/width ratio of the caudal rami of the Veracruz specimens (3.2-3.4) (Fig. 1K) is similar to that found in the Sinaloan (3.1-3.5) and the Morelos specimens (3.2-3.3). This range is closer to the proportions described in African populations (3.0-3.45) (Kiefer, 1981, Van de Velde, 1984) than to the Asian, which have a greater variation (2.7-3.6) (Holyńska, 2000). In the Veracruz specimens the length ratio of the caudal ramus / dorsal caudal seta is close to 1.1, whereas it is 1.5 in the Sinaloa specimens and 1.8 in the Morelos population. Other measurements relative to the caudal setae in the Veracruz specimens are: length ratio of dorsal/lateralmost terminal $=0.95-1.0$; longest terminal caudal seta/urosome $=1.17-1.2$. Relative length of terminal caudal setae III-VI from inner to outer margin= 2.9-3.0 (VI), 6.5-6.6 (V), 4.8-5.0 (IV), 1.0 (III). Of course, the range of variation of these measurements should be confirmed with a higher number of specimens, which are not currently available; however, the evaluation of these selected characters should be considered in future inter-population comparisons.

As recorded in the Sinaloa (Gutiérrez-Aguirre et al., 2002) and the Morelos (Elías-Gutiérrez et al., 2008) populations, only females were collected in Veracruz. Males of this species are rare (Reid and Saunders, 1986) and comparative morphological data are still limited (Holyńska et al., 2003).

\section{Taxonomic Summary}

Material examined.- Adult female from pond in El Castillo, Jalapa, Veracruz, Mexico (19॰32'45” N; 96 51' 44” W), sampled 18 September 2007 by Ruth Hernández, specimen dissected, semi-permanent slide (ECO-CHZ-03960). Adult female from same locality and date, undissected, ethanolpreserved, vial (ECO-CHZ-03861). Three adult females from Barranca de Jantetelco (18 42' 47” N; 98 45' 47" W), sampled 16 January 2002 by M. Elías, undissected, ethanol-preserved, vial (ECO-CHZ-02392).

\section{Remarks}

This is considered to be a pantropical species that usually occurs in low numbers but in a wide variety of habitats (Holyńska et al., 2003). The overall known latitudinal range of this species extends from the $33^{\circ} \mathrm{N}$ to $28^{\circ} \mathrm{S}$, thus including some subtropical areas of the world. In the Americas this species ranges between the $25^{\circ} \mathrm{N}$ (Sinaloa, Mexico) (Gutiérrez-Aguirre et al., 2003a) and $28^{\circ} \mathrm{S}$ (middle Paraná river, Argentina) (Dussart and Frutos, 1985). According to Holyńska et al. (2003), there are 2 main forms of M. aspericornis with a defined geographical distribution. These are separated by the presence (western populations including West Africa and the Neoptropics) or absence (eastern populations including Central and Eastern Asia) of a row of small spinules next to the distal 


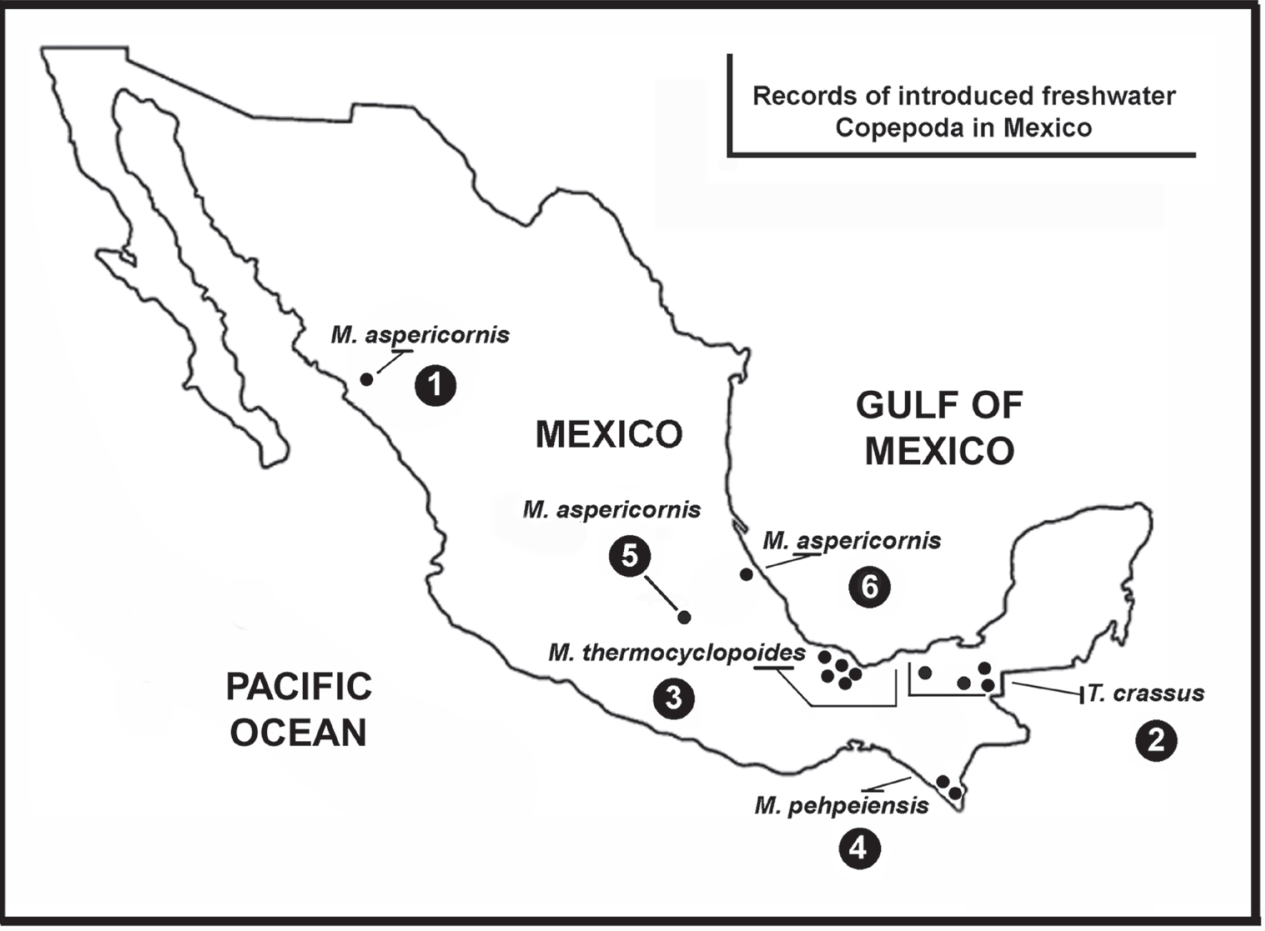

Figure 2. Distribution of records of exotic freshwater cyclopoid copepods in Mexico. 1, Mesocyclops aspericornis in Sinaloa (Gutiérrez-Aguirre et al., 2003a); 2, Thermocyclops crassus in Tabasco (Gutiérrez-Aguirre and Suárez-Morales, 2000); 3, M. thermocyclopoides in Tabasco (Gutiérrez-Aguirre et al. 2003b); 4, M. pehpeiensis in Chiapas (Suárez-Morales et al., 2005); 5, M. aspericornis in Morelos (Elías-Gutiérrez et al., 2008); 6, M. aspericornis in Veracruz (this contribution). rim of the caudal surface of the antennal basipodite. These spinules are clearly present in the Mexican specimens (Veracruz, Morelos, and Sinaloa). This character, found in all the Mexican specimens, relates them to the western populations; hence, this "western" form is most probably the one reported in the Americas.

Most of the known American records of $M$. aspericornis are related to the Atlantic coast (Caribbean islands, South America); however, the finding of $M$. aspericornis in the Gulf of Mexico area was unexpected due to the lack of previous records in Central America and southeast Mexico (SuárezMorales \& GutiérrezAguirre, 2001). The closest record is that from Morelos, in central Mexico (see Fig. 2). We speculate here around 2 hypotheses: (1) that the occurrence of this species in Veracruz could be related to northwards dispersal from the Atlantic coast of South America (Colombia, Venezuela). The efficient dispersal means of this species (Reid and Saunders, 1986) would allow it to advance through Central America, Southeast and central Mexico to reach Veracruz. The lack of records of this species from Central America or southeast Mexico (Gutiérrez-Aguirre et al., 2003a), could result from insufficient sampling and identification efforts in this area. Alternatively, the finding of this species in central Veracruz could be attributed to human intervention through aquacultural activities along the gulf coast. The same was hypothesized for the record of $M$. aspericornis in Sinaloa (Gutiérrez-Aguirre et al., 2003a) and for M. pehpeiensis in Chiapas (Suárez-Morales et al., 2005), both related to highly active areas for aquaculture in the Pacific coast. A similar situation could explain the occurrence of this species in Morelos, an area of Mexico with important aquacultural activity. Aquaculture is widely known as one of the main causes favoring introduction of exotic copepod fauna worldwide (Reid and Pinto-Coelho, 1994; Okolodkov et al., 2007). Because of their relative geographical and orographical isolation from each other and from the nearest records, the 3 Mexican records of $M$. aspericornis could well be the result of 3 independent events of dispersal or introduction by human activity. On the other hand the case of Thermocyclops crassus, another exotic copepod recorded in southeast Mexico, appears to be different; it was most probably related to dispersal from Central America, where this species was reported long before it was found in Mexico (Gutiérrez-Aguirre and Suárez-Morales, 2000), but the original arrival to the continent seems to be human related. An intensive sampling effort in Central America and southeast Mexico could provide important data to define the origin and track the dispersion of these apparently isolated populations of M. aspericornis in Mexico. Some of the Afro-Asian species of Mesocyclops known to occur in the Americas have a morphological resemblance with native forms. The scarceness of taxonomical expertise in identifying freshwater copepods could be another factor that has delayed the detection of other populations in Mexico and 
the Neotropical region (Suárez-Morales et al., 1999).

The present record is considered to be the sixth exotic species of freshwater cyclopoid copepods in Mexico (see Fig. 2). Records include M. aspericornis (GutiérrezAguirre et al., 2003a; Elías-Gutiérrez et al., 2008), the Euroasian Thermocyclops crasssus (Fischer, 1853) (Gutiérrez-Aguirre and Suárez-Morales, 2000), the AfroAsian M. thermocyclopoides (Gutiérrez-Aguirre et al., 2003b), and the Asian M. pehpeiensis (Suárez-Morales et al., 2005) (see Okolodkov et al., 2007). The latter species was also recorded in Cuba (Menéndez-Díaz et al., 2006). It is relevant to mention that 3 out of the 4 exotic cyclopoid species currently known in Mexico were recorded from the southeastern region of the country, particularly from the states of Tabasco (M. thermocyclopoides, T. crassus) on the Atlantic coast, and Chiapas (M. pehpeiensis) on the Pacific coast.

Mesocyclops aspericornis is an epibenthic form dwelling in the littoral zones (Reid and Saunders, 1986) but it has been collected in a wide variety of freshwater environments, including extreme habitats, from small containers to large lakes (see Reid and Saunders, 1986, Gutiérrez-Aguirre et al., 2003a). Hence, the temporal pond surveyed in Veracruz is within this environmental range and the species could be present in other similar localities.

\section{Acknowledgements}

This work is part of a project developed by Servicios de Salud de Veracruz in Jalapa, Veracruz to explore the local copepod fauna as possible source of agents for mosquito control. Sergio Ibáñez-Bernal (INECOL) and Ruth Hernández-Xoliot (SESVER), of the VECTOVER (Vectores de Veracruz) team, and the entomologists Israel Villa, Carlos García, Mario Vázquez, and Marco Galindo contributed in different aspects to this project.

\section{Literature cited}

Dussart, B. H. and M. Frutos. 1985. Sur quelques copépodes d'Argentine. Revue d' Hydrobiologie Tropicale 18:305-314.

Elías-Gutiérrez, M., E. Suárez-Morales, M. A. Gutiérrez-Aguirre, M. Silva-Briano, J. G. Granados and T. Garfias. 2008. Cladocera y Copepoda de las aguas continentales de México. Guía ilustrada. ECOSUR/UNAM-Iztacala/CONABIO/ CONACYT, México. 322 p.

Gutiérrez-Aguirre, M. A. and E. Suárez-Morales. 2000. The Euroasian Thermocyclops crassus (Fischer, 1853) (Copepoda, Cyclopoida) found in Southeastern Mexico.
Crustaceana 73:705-713.

Gutiérrez-Aguirre, M. A., E. Suárez-Morales and M. SilvaBriano. 2003a. The Afro-Asian Mesocyclops aspericornis (von Daday) (Copepoda, Cyclopidae) in Mexico: comments on morphology and distribution. Crustaceana 75:1349-1362.

Gutiérrez-Aguirre, M. A., J. W. Reid and E. Suárez-Morales. 2003b. An Afro-Asian species of Mesocyclops (Copepoda: Cyclopoida) in Central America and Mexico. Journal of Crustacean Biology 23:352-363.

Holyńska, M. 2000. Revision of the Australasian species of the genus Mesocyclops Sars, 1914 (Copepoda, Cyclopidae). Annales Zoologici 50:363-447.

Holyńska, M., J.W. Reid and H. Ueda. 2003. Genus Mesocyclops Sars, 1914. In Copepoda: Cyclopoida genera Mesocyclops and Thermocyclops, H. Ueda and J. W. Reid (eds.). Guides to the identification of the microinvertebrates of the continental waters of the world. 20. Backhuys, Amsterdam. 213 p.

Kiefer, F. 1981. Beitrag zur Kenntnis von Morphologie, Taxonomie und geographischer Verbreitung von Mesocyclops leuckarti auctorum. Archiv für Hydrobiologie, Suppl. 62, Monographischer Beiträge 1:148-190.

Marten, G.G., E. S. Bordes and M. Nguyen, 1994. Use of cyclopoid copepods for mosquito control. Hydrobiologia 292/293:491-496.

Mendoza, F. 2007. Diversidad y hábitats acuáticos de mosquitos (Diptera: Culicidae) en la región central de Veracruz, México. Tesis Doctoral. Instituto de Ecología. 93 p.

Menéndez-Díaz, Z., J. W. Reid, I. Castillo and I. Valdés. 2006. A new record of Mesocyclops pehpeiensis $\mathrm{Hu}, 1943$ (Copepoda: Cyclopoida) for Cuba. Journal of Vector Ecology 31:193195.

Okolodkov, Y. B., R. Bastida-Zavala, A. L. Ibáñez, J. W. Chapman, E. Suárez-Morales, F. Pedroche and F. J. Gutiérrez-Mendieta. 2007. Especies acuáticas no indígenas en México. Ciencia y Mar 9:29-67.

Pesce, G. L. 1985. Cyclopids (Crustacea, Copepoda) from West Indian groundwater habitats. Bijdragen tot de Dierkunde 55:295-323.

Reid, J. W. and R. M. Pinto-Coelho. 1994. An Afro-Asian continental copepod, Mesocyclops ogunnus, found in Brazil; with a new key to the species of Mesocyclops in South America and a review of intercontinental introductions of copepods. Limnologica 24:359-368.

Reid, J. W. and J. F. Saunders. 1986. The distribution of Mesocyclops aspericornis (von Daday) in South America. Journal of Crustacean Biology 6:820-824.

Rocha C. E. F. and M. J. C. Botelho. 1998. MaxillopodaCopepoda, Cyclopoida. In Catalogue of Crustacea of Brazil, P. S. Young (ed.). Museu Nacional, Rio de Janeiro. p. 129166.

Suárez, M. F., D. Ayala, M. J. Nelson and J. W. Reid. 1984. Hallazgo de Mesocyclops aspericornis (Daday) (Copepoda: 
Cyclopidae) depredador de larvas de Aedes aegypti en Anapoima-Colombia. Biomédica 4:74-76.

Suárez-Morales E. and M. A. Gutiérrez-Aguirre. 2001. Morfología y taxonomía de los Mesocyclops (Crustacea, Copepoda, Cyclopida) de México. CONACYT/ ECOSUR, México. 202 p.

Suárez-Morales E. and J. W. Reid. 1998. An updated list of the free-living freshwater copepods (Crustacea) of Mexico. Southwestern Naturalist 43:256-265.

Suárez-Morales, E., J. A. Mclelland and J. W. Reid. 1999. The planktonic copepods of coastal saline ponds of the Cayman Islands with special reference to the occurrence of Mesocyclops ogunnus Onabamiro, an apparently introduced
Afro-Asian cyclopoid. Gulf Research Reports 11:51-56.

Suárez-Morales, E., M. A. Gutiérrez-Aguirre and M. ElíasGutiérrez. 2003. Observations on the structure of the mandible edge in some American Mesocyclops (Copepoda: Cyclopidae). Proceedings of the Biological Society of Washington 116:742-753.

Suárez-Morales, E., M. A. Gutiérrez-Aguirre, J. L. Torres and F. Hernández. 2005. The Asian Mesocyclops pehpeiensis Hu, 1943 (Copepoda, Cyclopidae) in Southeast Mexico with comments on the distribution of the species. Zoosystema 27:245-256.

Van de Velde, I. 1984. Revision of the African species of the genus Mesocyclops Sars, 1914 (Copepoda, Cyclopidae). Hydrobiologia 109: 3-66. 
